\title{
Feminist Reflections on the Responsibility to Protect
}

\author{
Hilary Charlesworth* \\ Australian National University \\ CharlesworthH@law.anu.edu.au
}

\begin{abstract}
This paper offers a feminist analysis of the responsibility to protect principle. It outlines some themes in feminist scholarship in international law and then uses these to explore the idea of a responsibility to protect. The paper argues that, despite some resonance with feminist concerns, the doctrine has been developed in a limited context, effectively privileging male elites and masculine modes of reasoning.
\end{abstract}

\section{Keywords}

Responsibility to protect, International law, Feminist theory, Intervention, Discrimination, Violence against women

\section{Introduction}

The identification and promotion of the 'responsibility to protect' principle over the last decade provides a case study of the techniques of modern international law-making. International law is a complex mix of normative and justificatory principles, a brew aptly captured by Martti Koskenniemi in his description of international legal argument as an oscillation between utopian and apologetic positions. ${ }^{1}$ Unlike most national legal systems, the political roots of international law are constantly on display and it is difficult to avoid moral and philosophical debate in discussing its scope. The development of the responsibility to protect doctrine illustrates the power of a strong normative concept in responding to massive atrocities, accompanied by an apparently

* Thanks to Susan Harris Rimmer for her comments on this paper.

${ }^{1}$ Martti Koskenniemi, From Apology to Utopia: The Structure of International Legal Argument (Cambridge and New York: Cambridge University Press, 2006). 
concrete set of conditions for its operation, an edgy acronym, R2P, ${ }^{2}$ and energetic, experienced and well-resourced norm-entrepreneurs.

This paper investigates the implications of the responsibility to protect principle from a feminist perspective. Such an approach is generally marginalised in mainstream international law discourse and it is also absent from discussions of the responsibility to protect doctrine. The paper argues that the responsibility to protect has developed without adequate attention to the lives of women. The principle also depends on gendered accounts of the value of military intervention in international affairs that limit the possible responses to atrocities.

The idea that states have a responsibility to protect their populations was first articulated by the International Commission on Intervention and State (ICISS) in 2001. The ICISS was established by the Canadian government to respond to a challenge identified by United Nations (UN) Secretary-General Kofi Annan at the UN Millennium Summit in 2000. Annan had reflected on two political and moral disasters of the preceding decade: the failures to prevent the genocide in Rwanda in 1994 and the slaughter of civilians in a UN safe haven in Srebrenica in Bosnia in 1995. He observed the strength of the concept of state sovereignty as a major barrier to action, one that inevitably undermined any external claim to 'humanitarian' intervention. Annan called for new ways of thinking about sovereignty to avert situations 'that offend every precept of our common humanity'. ${ }^{3}$ The Commission articulated the principle of responsibility to protect as a way of short-circuiting the longstanding debate between proponents of a right to intervene in states on humanitarian grounds on the one hand and protectors of maximum state sovereignty on the other. ${ }^{4}$ Sovereignty was conceptualised as responsibility rather than authority. ${ }^{5}$ The notion of responsibility to protect was designed to change the perspective in responding to mass atrocity from that of the prospective interveners or resisters to that of the victims of the atrocities. ${ }^{6}$

${ }^{2}$ Gareth Evans suggests that the shorthand term R2P was devised 'under the universal cultural influence of Star Wars and its engagingly determined little droid R2-D2': Gareth Evans, The Responsibility to Protect: Ending Mass Atrocity Crimes Once and For All (Washington: The Brookings Institution, 2008), p. 5.

${ }^{3}$ Kofi Annan, Millennium Report of the Secretary-General of the United Nations, A/54/2000, 3 April 2000.

${ }^{4}$ International Commission on Intervention and State Sovereignty (ICISS), The Responsibility to Protect (Ottawa: IDRC, 2001); see also Evans, The Responsibility to Protect, pp. 38-43.

${ }^{5}$ Ramesh Thakur, The United Nations, Peace and Security (Cambridge: Cambridge University Press, 2007), p. 255.

${ }^{6}$ Evans, The Responsibility to Protect, p. 40. 
The responsibility to protect a population rests, first, with a state. If a state is unable or unwilling to protect its citizens, then the responsibility moves to the international community collectively.

The responsibility to protect principle gained momentum through its endorsement by a High-Level UN Panel on Threats, Challenges, and Change in 2004, preparing for the UN's sixtieth anniversary in 2005. ' The panel spoke of an 'emerging norm that there is a collective international responsibility to protect, exercisable by the Security Council authorizing military intervention as a last resort, in the event of genocide and other large-scale killing, ethnic cleansing or serious violation of international humanitarian law which sovereign governments have proved powerless or unwilling to prevent. ${ }^{8}$ Kofi Annan then embraced the principle in his report to the 2005 World Summit. ${ }^{9}$ The principle's significance was consolidated by inclusion in the UN General Assembly's World Summit Outcomes document. ${ }^{10}$ Each iteration of the principle altered its coverage and emphasis. ${ }^{11}$ For example, the 2005 version omits reference to the ICISS proposal that permanent members of the Security Council should refrain from using their veto in cases of intervention if their own national security interests were not compromised. Another change from the ICISS report, which linked the operation of the responsibility to protect to the broad category of occasions of 'serious harm', was to tie it to the occurrence of four international crimes: genocide, war crimes, ethnic cleansing and crimes against humanity. ${ }^{12}$

As UN Secretary-General, Ban Ki-moon has supported and developed the responsibility to protect concept, appointing a special adviser on the topic,

7 Gareth Evans, the Co-Chair of the ICISS, was a member of the High-Level Panel.

${ }^{8}$ High Level Panel on Threats, Challenges, and Change, A More Secure World: Our Shared Responsibility (New York: United Nations, 2004), p. 106 para. 203.

9 In Larger Freedom: Towards Development, Security and Human Rights for All, A/59/2005, 21 March 2005, para. 135.

10 '2005 World Summit Outcome', A/RES/60/1, 24 October 2005, paras. 138-139. For the politics of the negotiations behind this document, see Alex Bellamy, 'Whither the Responsibility to Protect? Humanitarian Intervention and the 2005 World Summit', Ethics and International Affairs, 20/2: 143-69 (2006); Gareth Evans, 'From Humanitarian Intervention to R2P', Wisconsin International Law Journal, 24/3: 703-22 (2006).

${ }^{11}$ See Nicholas Wheeler, 'A Victory for Common Humanity? The Responsibility to Protect after the 2005 World Summit'. paper presented at The UN at Sixty: Celebration or Wake?', University of Toronto, 6-7 October 2005. Gareth Evans argues however that the various formulations are not significantly different: Evans, The Responsibility to Protect, p. 47.

12 This change was proposed by Pakistan in order to prevent the concept being used by strong countries against weaker ones: Anne Orford, 'Jurisdiction without Territory: From the Holy Roman Empire to the Responsibility to Protect', Michigan Journal of International Law, 30/3: 981-1015 (2009), p. 1006. 
Edward Luck. Ban Ki-moon has set out to 'operationalise' the principle, elaborating it as consisting of three 'coequal and mutually reinforcing' pillars: the responsibility of individual states to protect their population from the four international crimes; the responsibility of the international community to assist states to meet this responsibility; and the responsibility of the international community to take timely and decisive collective action under the UN Charter if states are not meeting their individual responsibilities to their citizens. ${ }^{13}$

The responsibility to protect principle has encountered tough resistance politically, particularly from some developing states. ${ }^{14}$ Despite its uncertain political and legal status, formulation of the responsibility to protect doctrine allows lawyers, politicians and civil society to feel that they are actively resisting injustice. The principle's strength comes from its rejection of a rule of might and its commitment to a higher norm of protection. At the same time, the reception of the principle demonstrates the way that invocations of notions of state sovereignty become a standard realist counter-move to undercut utopian ambitions.

Gareth Evans, the tireless campaigner for the responsibility to protect, regards the imprimatur of international lawyers as significant in the recognition of the principle because international law, unlike its domestic counterpart, is capable of evolving through practice and commentary as well as through formal instruments and judicial decisions'. ${ }^{15}$ And yet he is ambivalent about the place of law in the concept, which is explicitly moral. ${ }^{16}$ International lawyers have approached the responsibility to protect principle warily. Some are attracted to its grand humanitarian vision, but acknowledge that the doctrine is at best de lege ferenda, an emerging principle of international law that as yet has no independent legal status. ${ }^{17}$ Others are sceptical of the concept of a responsibility to protect, regarding it as a reincarnation of the controversial

13 Ban Ki-moon, Implementing the Responsibility to Protect, A/63/677, 12 January 2009.

${ }_{14}$ See Evans, The Responsibility to Protect, pp. 52-3; Office of the President of the General Assembly, Concept Note on the Responsibility to Protect Populations from Genocide, War Crimes, Ethnic Cleansing and Crimes against Humanity, 17 July 2009.

15 Evans, The Responsibility to Protect, p. 44.

${ }^{16}$ Ibid., pp. 146-47.

${ }_{17}$ See, for example, Jutta Brunée and Stephen Toope, 'Norms, Institutions and UN Reform: The Responsibility to Protect', Journal of International Law \& International Relations, 2/1: 121- 37 (2005), p. 133; Carsten Stahn, 'Responsibility to Protect: Political Rhetoric or Emerging Legal Norm?', American Journal of International Law, 101/1: 99-120 (2007); Ekkehard Strauss, 'A Bird in the Hand is Worth Two in the Bush: On the Assumed Legal Nature of the Responsibility to Protect', Global Responsibility to Protect, 1/3, 291-323 (2009). 
idea of humanitarian intervention; a carapace for oppressive interference by strong states into weak ones. ${ }^{18}$ The legal debate has centred on the relationship of the principle to state sovereignty: whether it is consistent with sovereign statehood, or whether it interferes with sovereignty in a fundamental way.

There is now a considerable literature on the idea of the responsibility to protect. It has been explored and critiqued from many angles: for example, does the concept create a moral hazard, encouraging resort to violence by oppressed groups because of the expectation of intervention on their behalf by the international community $;^{19}$ does it ignore the concerns of the global South and simply legitimate colonial patterns of intervention?; ${ }^{20}$ does it produce an international community with almost unfettered powers of intervention? ${ }^{21} \mathrm{~A}$ relatively unexplored dimension of the principle by both advocates and critics is, however, its relationship to sex and gender.

\section{Feminist scholarship in international law}

The aim of feminism is to advance the equality of women. Feminist scholarship is inspired by this political project, but has proposed many different, and sometimes contradictory, ways of describing and understanding women's inequality. Feminist theories inevitably rest on a tension between their role analysing the masculinity of disciplinary knowledge and their role as a response to political feminist goals. For this reason they often incur not only the wrath of the traditional academy because of their overtly political ends, but also the ire of feminist activists because they engage with the male-dominated world of theory. ${ }^{22}$ In a legal context, feminist theory has been described as 'an analysis of the exclusion of (some) women's needs, interests, aspirations, or attributes from the design or application of the law. ${ }^{23}$

${ }^{18}$ See, for example, José E. Alvarez, 'The Schizophrenias of R2P', paper presented at The Hague Joint Conference on Contemporary Issues of International Law, 30 June 2007.

19 Alan J. Kuperman, 'The Moral Hazard of Humanitarian Intervention: Lessons from the Balkans', International Studies Quarterly, 52/1: 49-80 (2008).

${ }^{20}$ David Chandler, 'The Responsibility to Protect? Imposing the "Liberal Peace", International Peacekeeping, 11/1: 59-81 (2004), p. 68.

${ }^{21}$ Orford, 'Jurisdiction without Territory', pp. 1013-1015.

22 Elizabeth Grosz, 'A note on essentialism and difference' in Sneja Gunew (ed.), Feminist Knowledge: Critique and Construct (London and New York: Routledge, 1990), p. 332.

${ }^{23}$ Denise Réaume, 'What's Feminist about a Feminist Analysis of Law?', Legal Theory 2/4, 256-299 (1996), at p. 271. 
Feminist scholars have argued that international law generally is both sexed and gendered, challenging the assumption that international law offers a rational detached universal form of justice. One way that feminist scholars make this argument is to investigate where women are located in international law what roles are they assigned, and what benefits does international law offer them? This can be understood as a question about sex in the sense that it is interested in women as distinct from men in a biological sense. ${ }^{24}$ Another feminist technique is to ask how the idea of gender shapes international legal concepts. ${ }^{25}$

Where are the women in international law? We could note, first, that there is a disproportionate representation of men in the institutions of international law. The International Court of Justice, the premier judicial body of the international legal system, has in 2010 no woman among the fifteen elected judges. Only one woman, Dame Rosalyn Higgins, has ever been elected to the Court, and one woman, Professor Suzanne Bastid, has been appointed as a judge ad hoc. The International Law Commission, established under the UN Charter, a prestigious body of forty-five jurists, has three women members in 2010 . The UN Secretariat is dominated by men, as are the expert committees monitoring the human rights treaties of the UN. One important exception to this is the International Criminal Court, which has eleven women judges among its eighteen members. Feminist scholars point out that not only are few women involved in the formal international legal system, but also the categories and concepts of international law do not accommodate the realities of most women's lives. ${ }^{26}$

Feminist analysis has pointed to the way that the exclusion of women's lives has affected the development of international law. For example, why are migratory species of sea life regulated by treaty when the use of breast milk substitutes, which is a major health issue for women in Africa, remains subject to voluntary World Health Organization codes? Why is extra-territorial jurisdiction,

${ }^{24}$ The distinction between sex and gender on the basis of biological characteristics has been criticised by some feminist scholars: see Margaret Davies, 'Taking the Inside Out: Sex and Gender in the Legal Subject' in Ngaire Naffine and Rosemary Owens (eds.), Sexing the Subject of Law (Sydney: Law Book Company, 1997).

${ }^{25}$ Marysia Zalewski, 'Well, What is the Feminist Perspective on Bosnia?' International Affairs, 71/2: 339-56 (1995). See also Cynthia Enloe, The Curious Feminist: Searching for Women in a New Age of Empire (Berkeley: University of California Press, 2004).

${ }^{26}$ See generally Hilary Charlesworth and Christine Chinkin, The Boundaries of International Law: A Feminist Analysis (Manchester: Manchester University Press, 2000); Doris Buss and Ambreena Manji (eds.), International Law: Modern Feminist Approaches (Oxford and Portland: Hart Publishing, 2005). 
traditionally invoked against violations of monopoly and competition law, only rarely used in cases of trafficking of women and children? ${ }^{27}$

What work is gender doing in international law? Feminists have argued that the language and imagery of the law draw on gendered categories: international law lays claim to rationality, objectiveness and abstraction, characteristics traditionally associated with Western masculinity, and it is defined in contrast to emotion, subjectivity, and contextualised thinking. The power of international legal discourse rests on a series of binary oppositions: order/chaos, logic/ emotion, legal/political, and binding/non-binding. Feminist scholars have pointed to the gendered coding of these dichotomies, with the stronger term associated with masculinity and the less preferable one with femininity.

There has also been considerable debate within international legal feminist scholarship. For example, Ratna Kapur has criticised what she terms the victimisation' rhetoric used by the international human rights movement when discussing the situation of Third World women, particularly in relation to violence and trafficking. Kapur argues that the assumption of a common international women's victimhood operates to keep women in their place by presenting them as both vulnerable and ignorant. ${ }^{28}$ She has rejected a focus on the sexual as the locus of women's oppression and has urged a more complex understanding of women's lives through considering factors such as race, wealth, class and religion. Anne Orford has also tracked the relationship between feminism and imperialism, cautioning against an approach that simply moves women from the private to public domain. She has drawn attention to the way that intervention narratives depend upon the construction of a gendered and racialised 'other' which makes intervention appear the only acceptable response to atrocities. ${ }^{29}$

Critical work on feminism in international law, then, has asked questions about the location of women in its structures and investigated the role that gender plays in its formation. At the same time international law has also been invoked in feminist struggles as a source of transformation and empowerment. This has created a certain tension within feminist international legal scholarship, and sometimes a fractured politics. ${ }^{30}$

${ }_{27}$ Charlesworth and Chinkin, The Boundaries of International Law, chapter 1.

${ }^{28}$ Ratna Kapur, 'The Tragedy of Victimization Rhetoric: Resurrecting the "Native" Subject in International/Post-Colonial Feminist Legal Politics' Harvard Human Rights Law Journal, 15/1, 1-37 (2002).

29 Anne Orford, Reading Humanitarian Intervention: Human Rights and the Use of Force in International Law (Cambridge: Cambridge University Press, 2003), pp. 56-71.

${ }^{30}$ Marysia Zalewski has described a parallel debate within feminist international relations scholarship: 'Do We Understand Each Other Yet? Troubling Feminist Encounters With(in) 
A central concern of feminism is the location of power within a society; scholars have emphasised the dispersal of power and the fact that it does not 'reside only and always in a centre' leaving women on its periphery. ${ }^{31}$ For this reason, as Sneja Gunew has pointed out, '[feminism] is not simply a question of storming a series of male citadels and occupying the controls.' Feminist inquiry involves attention to the way that power produces knowledge and ideas. If power is understood as a network, operating in complex and inconsistent ways, the possibilities of resisting it in different contexts increase. ${ }^{32}$

Because of the considerable scholarly literature in this area over the last two decades, some feminist ideas have now been absorbed into the rhetoric of international law and its institutions. ${ }^{33}$ International women's groups have taken up feminist critiques of the international legal order and concepts such as 'gender mainstreaming' have been embraced in national, regional and international systems. In many areas, however, progress has been limited. Feminist issues have been either corralled in the margins of international law or rendered so bland that they have no transformative bite. ${ }^{34}$

\section{Feminist analysis of the responsibility to protect principle}

What feminist questions are raised by the responsibility to protect principle? On one level, the concept appears hospitable to feminist agendas. Its emphasis on a conditional, limited form of sovereignty departs from the traditional paradigm of sovereignty as autonomy and impermeability, which feminist scholars have linked to the male body. ${ }^{35}$ So too the language of responsibility resonates with research on the nature of female reasoning. For example, Carol

International Relations', British Journal of Politics and International Relations 9/2: 302-12 (2007).

${ }^{31}$ Sneja Gunew, 'Feminist Knowledge: Critique and Construct' in Sneja Gunew (ed.), Feminist Knowledge: Critique and Construct (New York: Routledge, 1990), p. 23.

${ }^{32}$ Ibid.

33 See Alice Edwards, 'Violence against Women as Sex Discrimination: Judging the Jurisprudence of the United Nations Human Rights Treaty Bodies', Texas Journal of Women \& the Law, 18: 1-44 (2008).

${ }^{34}$ Hilary Charlesworth, 'Not Waving but Drowning: Gender Mainstreaming and Human Rights', Harvard Human Rights Journal, 18, 1-18 (2005).

${ }^{35}$ See Hilary Charlesworth, 'The Sex of the State in International Law' in Ngaire Naffine and Rosemary Owens (eds.), Sexing the Subject of Law (Sydney: Law Book Company, 1997); Christine Sylvester, 'Feminists and Realists View Autonomy and Obligation in International Relations' in V. Spike Peterson (ed.), Gendered States: Feminist (Re)Visions of International Relations Theory (Boulder, Colorado, Lynne Rienner Press, 1992) p. 157. 
Gilligan's path-breaking work on modes of moral decision-making and problem-solving by girls and boys showed differences between them. Girls tended to reason on the basis of values such as caring and connection, while boys' decisions were influenced more by abstract logic. Responsibility for individuals and the community and the preservation of relationships figured more largely in decisions taken by girls. ${ }^{36}$ Gilligan observed that the psychological literature generally rated the masculine pattern of reasoning as more mature and developed. ${ }^{37}$ Her concern was the privileging of one perspective and the marginalising of alternative modes of reasoning. It might be argued that the responsibility to protect doctrine in this sense breaks away from the standard masculine forms of rationality endorsed in international law and international relations and allows an analysis based on a broader range of factors. By factoring in the needs of a population and downplaying the values of an abstract sovereignty, the doctrine can get around some of the inhumane aspects of realism and legalism.

Another aspect of the responsibility to protect doctrine that apparently responds to feminist critiques of the international security system is the prominence it gives to prevention of mass atrocities ('overwhelmingly the most important [responsibility] to pursue' $)^{38}$ and its emphasis on non-military modes of intervention. Gareth Evans reports that an impetus for the doctrine in the ICISS was precisely 'to sideline the humanitarian intervention terminology ... [which] had become irretrievably linked to the use of military force, and only military force, as a way to respond to actual or impending mass atrocities. ${ }^{39}$

A closer look at the concept of the responsibility to protect suggests however that it remains susceptible to feminist critique. Its design has been influenced by men's lives and the dominance of masculine modes of reasoning.

\section{Where are the women?}

Women have been largely absent from the development of the responsibility to protect principle. The ICISS had a single woman member, Gisele CôtéHarper, and eleven men. The High Level Panel had four women members (Gro Harlem Brundtland, Mary Hesse, Sadako Ogata and Nafis Sadik) and

\footnotetext{
${ }^{36}$ Carol Gilligan, In a Different Voice: Psychological Theory and Women's Development (Cambridge: Harvard University Press, 1982).

37 Ibid., pp. 9-18.

${ }^{38}$ Evans, The Responsibility to Protect, p. 43.

${ }^{39}$ Ibid., p. 40.
} 
twelve men. These are unexceptional figures in the international arena, but they underline the routine under-representation of women in the development of international law, despite widely-ratified treaty provisions that require the elimination of discrimination against women in political and public life. ${ }^{40}$

Would the participation of more women in the development of international norms affect the content of the norms? The evidence is uncertain as there are so few cases of norm-generation where equal numbers of women and men are involved. The sex of the architects of a principle does not necessarily determine the reach or significance of the concept, although it may affect the way that it is presented. But it is at least clear that the realities of women's lives do not contribute in any significant way to the shaping of international principles. Karen Knop has suggested that women's under-representation of women in international decision-making could be characterised as impinging on their 'collective autonomy' ${ }^{41}$ She has argued that 'women should be able to decide at least certain international issues not because they will decide them better than or even differently from men, but because they as a group ... should be able to make the decisions that affect their lives'. ${ }^{42}$

The representation of women's interests by men is complex. Anne Phillips points out that 'if women's interests were transparently obvious to any intelligent observer, there might be no particular case ... for insisting on representatives who also happen to be women.' If, on the contrary, women's interests are 'varied, unstable, perhaps still in the process of formation', the separation of the representative from what is to be represented is more difficult. ${ }^{43}$ In the international arena, the category of 'women's interests' is inevitably diverse; differences in culture, social and economic circumstances loom large in this context. For this reason, men's representation of women's interests is unlikely to be adequate. The imbalance in men's representation in decision-making structures at the international level allows male life experiences to be seen as a general, rather than a specific, category.

Proponents of the responsibility to protect principle assert its universal reach, a prerequisite for international legal status. However, there has been little study of the way that the principle might affect women's lives, or its

${ }^{40}$ For example, Convention on the Elimination of All Forms of Discrimination Against Women 1979, articles 7 and 8.

${ }^{41}$ Karen Knop 'Re/statements: Feminism and State Sovereignty in International Law', Transnational Law and Contemporary Problems, 3: 293-344 (1993), p. 306.

${ }^{42}$ Ibid., pp. 306-7.

${ }^{43}$ Anne Phillips, Engendering Democracy (Cambridge: Polity Press, 1991), p. 15. 
relationship to Security Council Resolution 1325, adopted in 2000, which urged increased participation of women in national and international institutions and mechanisms dealing with the prevention, management and resolution of conflict. ${ }^{44}$ The lives of women appear peripheral to the development of the responsibility to protect principle, except for occasional references to the need to protect women from mass rape. ${ }^{45}$ The principle focuses on the public realm of the state and the government as the source of injury, ${ }^{46}$ but for most women, danger comes from the 'private' realm of the family or community as much as from the state. Violence against women is at epidemic levels around the world, with two-thirds of women experiencing violence during their lives, mainly at the hands of men in their family. ${ }^{47}$ Discrimination against women in areas such as inheritance and family law is justified by custom or religion.

Gareth Evans' book length study of the responsibility to protect makes several references to women. Women appear as particular victims of mass atrocities, especially in the case of sexual crimes. ${ }^{48}$ Evans refers to the 'special needs' of women caught up in conflict, although he does not elaborate on what they are $;^{49}$ and he remarks on the problems women face under traditional justice mechanisms in places like Pakistan. ${ }^{50}$ Evans also presents women as the backbone of peace initiatives. He writes that women 'are often the key not only to preventing the re-emergence of violence and resolving ongoing conflict, but to rebuilding societies once the guns go silent.' ${ }^{51}$ This is because women 'tend to adopt a more inclusive approach toward security and address key social and economic issues that would otherwise be ignored. ${ }^{52} \mathrm{He}$ supports the appointment of women as Special Representatives of the UN Secretary-General ${ }^{53}$ and as UN police (especially because this will be useful in detecting sexual violence).$^{54}$ Evans also deplores the failure to give teeth to Security Council Resolution $1325 .{ }^{55}$ His brief depictions of women present them as either

${ }^{44}$ One exception is Marilou McPhedran, Laurel Sherret and Jennifer Bond, 'R2P Missing Women - Canada's Responsibility to Perceive', discussion paper for Fragile States Conference, 27 November 2005.

45 For example, ICISS, The Responsibility to Protect, paras. 2.29, 4.20.

46 Evans, The Responsibility to Protect, pp. 74-75.

47 Ban Ki-moon, Speech on International Women's Day, 8 March 2010.

${ }^{48}$ Evans, The Responsibility to Protect, p. 40.

49 Ibid., p. 156.

${ }^{50}$ Ibid., p. 168.

51 Ibid., p. 171. See also p. 156.

52 Ibid., p. 171.

53 Ibid., p. 203.

${ }_{54}$ Ibid., pp. 212-3.

55 Ibid., p. 203. 
victims of public crimes such as mass rape or as inclusive peacebuilders, both popular UN stereotypes. ${ }^{56}$ One implication of such images is that violence and conflict are the province of men; in Jean Bethke Elshtain's words, they allow 'the collective projection' of a pure and peaceful Other against which a violent male is constructed'. She refers to a 'nasty historic bargain' which allows women to remain removed from the fray while 'boys will be boys'. In other words, presenting women as integral to peace 'winds up endorsing indeed requiring — that which they would oppose'. ${ }^{57}$

Descriptions of the responsibility to protect doctrine make clear that it is designed to apply only in exceptional ('few and far between') circumstances. ${ }^{58}$ This is a pragmatic feature to shore up the legitimacy of the concept by reassuring states that it will only allow intervention in extreme cases, and to preserve its value as a 'rallying cry' ${ }^{59}$ Gareth Evans emphasises this by stating that the principle will not apply in 'common ... cases of conflict or human rights concerns' ${ }^{60}$ for example the spread of HIV/AIDS. The types of conduct that will trigger the responsibility to protect - genocide, war crimes, ethnic cleansing and crimes against humanity - are a very limited subset of inhuman behaviour. The principle thus excludes structural forms of discrimination and violence against women in both public and private areas from its purview, factors that account for greater, systemic, harms to women's lives than the four categories of international crimes it mentions. In this sense, the principle's dependence on international military intervention as the final guarantee against mass atrocities skews its coverage from large-scale forms of harm and violence that appear routine to occasional outbreaks of particular forms of public violence. Some feminist scholars have argued for an international legal principle that would allow military intervention to protect women's rights. ${ }^{61}$ The major problem with such a proposal is that it uses a volatile and risky technique to support women's equality, one that is easily misused and indeed capable of exacerbating violence against women. ${ }^{62}$

56 See Hilary Charlesworth, Are Women Peaceful? Reflections on the Role of Women in Peace-Building', Feminist Legal Studies, 16: 347-61 (2008).

57 Jean Bethke Elshtain, Women and War (Chicago: Chicago University Press, 1995), p. 265.

58 Evans, The Responsibility to Protect, p. 75.

59 Ibid., p. 69.

60 Ibid., p. 75; see also ibid., pp. 68-9.

61 For example, Catharine MacKinnon, Are Women Human? (Cambridge: Harvard University Press, 2007), pp. 271-72.

${ }^{6}$ See Karen Engle, "Calling in the Troops": The Uneasy Relationship among Women's Rights, Human Rights, and Humanitarian Intervention', Harvard Human Rights Journal, 20: 189-226 (2007). 
The responsibility to protect, whether in its prevention, reaction or rebuilding phases, requires the importation of expertise; it involves top-down intervention, with little emphasis on empowering local people, particularly women. ${ }^{63}$ Although some iterations of the principle support the inclusion of women in the public realm, they do not address discrimination against women in the private sphere where traditional or religious practices can perpetuate women's inferiority to men.

Another way that the responsibility to protect principle marginalises women's experiences is through the prominence it accords to ex-combatants in the context of peace-making and rebuilding after conflict. There is an assumption that brokering peace should primarily involve those who had engaged in armed conflict, most commonly men. Despite the effects of conflict on women, they are regarded as inappropriate participants in ending the fighting. ${ }^{64}$ The focus of rebuilding is on disarmament, demobilisation and reintegration of armed forces, ${ }^{65}$ and little attention is paid to the way that women are regularly excluded from the rebuilding process. In Angola, for example, women were marginalised in the peace process because of their emphasis on social welfare as opposed to military power, and because they had neither the power nor interest in threatening to disrupt the talks with violence. ${ }^{66}$ Women's rights are indeed often traded for the support of political factions in postconflict situations; for example in 2009 Hamid Karzai's government in Afghanistan shored up its popularity with Shia leaders by adopting a law that imposed extraordinary restrictions upon Shia women, including the requirement that a woman must obtain a male relative's permission to seek employment, granting custody of children to fathers and grandfathers only, and allowing a man to withhold food from his wife if she did not accede to his sexual demands. ${ }^{67}$ Through its focus on ex-combatants, then, the responsibility to protect principle does not offer any impetus for states to improve the position of women as part of rebuilding projects.

${ }^{63}$ Evans discusses the importance of local ownership using the example of East Timor (at pp. 162-63), but he does not address the problem of women being marginalised in local decision-making, as has occurred in that country.

${ }^{64}$ Ban Ki-moon, Women and Peace and Security, S/2009/465, 16 September 2009, para. 71.

${ }^{65}$ E.g. Evans, The Responsibility to Protect, pp. 154-56.

${ }^{66} \mathrm{~J}$. Zoe Wilson, 'State Making, Peacemaking, and the Inscription of Gendered Politics into Peace: Lessons from Angola' in Dyan Mazurana, Angela Raven-Roberts and Jane Parpart (eds.), Gender, Conflict, and Peacekeeping (Boulder, Colorado: Rowman and Littlefield, 2005), p. 252.

${ }^{67}$ See Human Rights Watch, 'Afghanistan: Law Curbing Women's Human Rights Takes Effect', 13 August 2009, http://www.hrw.org/en/news/2009/08/13/afghanistan-law-curbingwomen-s-rights-takes-effect, accessed 10 March 2010. 
While Security Council Resolution 1325 can be criticised for being rather limited in the roles it imagines for women in peace-making and peacebuilding, ${ }^{68}$ the UN and its members have failed to take its modest prescriptions seriously. References to the need to include women in peace processes have become ritualistic in international institutions, but result in little change. For example, a UNIFEM study in 2009 found that only 2.4 per cent of signatories to peace agreements since 1992 had been women and that no woman had ever been designated as a 'chief mediator'. ${ }^{69}$

\section{What work is gender doing?}

Investigating gender can be 'a conceptual tool to make us see things at work that we would rather not see. ${ }^{70} \mathrm{I}$ use the term 'gender' here to mean the socially constructed categories of masculinity and femininity. This is distinct from the characteristics of particular men and women. The content of the categories of masculinity and femininity alters across time and cultures, but these concepts are typically defined in contrast to one other. ${ }^{71}$ Thus the essence of being masculine is to be not feminine. Another feature of gender is that what is deemed masculine is typically assigned a greater value than what is defined as feminine. ${ }^{72}$ Images of gender frame our political life; leadership is understood as requiring decisiveness, objectivity and rationality, detachment from the messiness of ordinary life. The vocabulary of objectivity, logic and order positions a person as being manly, which immediately gives their words a higher value. The use of subjective, emotional or 'disordered' discourse is coded as feminine and thus devalues a statement or argument. ${ }^{73}$

Gender informs the responsibility to protect doctrine in a number of ways. For example, Gareth Evans' account of his identification of and campaigning for the principle emphasises the role of the bold, fearless, decisive hero

${ }^{68}$ See Charlesworth, 'Are Women Peaceful?'.

${ }^{69}$ Cited in Ban Ki-moon, Women and Peace and Security, S/2009/465, 16 September 2009, para. 21.

${ }^{70}$ Cynthia Enloe, cited in Angela Raven-Roberts, 'Gender Mainstreaming in United Nations Peacekeeping Operations' in Dyan Mazurana, Angela Raven-Roberts and Jane Parpart (eds.), Gender, Conflict, and Peacekeeping (Boulder, Colorado: Rowman and Littlefield, 2005), p. 43.

${ }^{71}$ Joan Scott, 'Gender: A Useful Category of Analysis', American Historical Review, 91: 105375 (1986).

${ }^{72}$ Zalewski, 'Well, What is the Feminist Perspective on Bosnia?'.

${ }^{73}$ Carol Cohn, 'War, Wimps, and Women: Talking Gender and Thinking War' in Miriam Cooke and Angela Woollacott (eds.), Gendering War Talk (Princeton: Princeton University Press, 1993), p. 397. 
overcoming resistance and scepticism to produce a formula that will change international politics. Evans credits 'a fairly unquenchable sense of optimism' as the source of his energy in shepherding the responsibility to protect principle through international institutions. He is also sustained by 'a belief that even the most horrible and intractable problems are soluble; that rational solutions for which there are good, principled arguments do eventually prevail; and that good people, good governments, and good governance will eventually prevail over bad. ${ }^{74}$ The principle is described as one that can, properly applied, solve the problem of mass atrocities 'once and for all'; it is the single solution to the problem. ${ }^{75}$ There are close shaves and lucky breaks on the journey, but the principle of responsibility to protect, once identified, must remain pure and undiluted. ${ }^{76}$

Evans presents the principle as a basis for action in a programmatic, objective, quasi-scientific way, although its major components are all indeterminate and open to contestation. His account of the responsibility to protect depicts the use of force as a last resort, ${ }^{77}$ but it is also a vital guarantee of effectiveness for him. 'When is it right to fight?' Evans asks, as he reasons 'if there is one thing as bad as using military force when we should not, it is not using military force when we should. ${ }^{78}$ Evans proposes five criteria for the legitimate use of force as part of the responsibility to protect, drawn from just war theories. ${ }^{79}$ The description of the scope and implementation of the principle is built on a series of contrasts that draw their power from gendered images: for example humanitarian action as opposed to inaction; force as opposed to passivity; order as opposed to disorder and chaos; practicality as opposed to theory; optimism as opposed to pessimism. In this version of 'muscular humanitarianism $^{80}$ action, force, order, practicality and optimism are associated with masculine behaviour and their contrasts appear weak and feminine.

This account of the responsibility to protect does not pay adequate attention to the effects of intervention; indeed intervention prompted by just motives is assumed to be a positive force, whereas, as Anne Orford has noted, 'when we join our voices to the call for military intervention in a particular situation, we may find ourselves part of a different narrative. ${ }^{\prime 81}$ One of Evans'

\footnotetext{
74 Evans, The Responsibility to Protect, p. 7.

75 Ibid., p. 11.

76 Ibid., pp. 64-5.

77 Ibid., p. 213

${ }_{78}$ Ibid., p. 128 (emphasis in the original).

79 These criteria were originally formulated in the ICISS report: ibid. pp. 140-47.

${ }^{80}$ Orford, Reading Humanitarian Intervention, p. 7.

${ }^{81}$ Ibid., p. 37.
} 
criteria of legitimate force is consideration of the balance of consequences of military action, but the inquiry into consequences is framed narrowly as 'halting or averting the atrocities or suffering that triggered the intervention in the first place. ${ }^{82}$ Catastrophes that attract intervention are rarely discrete and susceptible to a neat resolution; they are better understood as protracted crises of security, financing, power and legitimacy, engineered by political elites, invariably dominated by men. ${ }^{83}$ The politics of masculinity and femininity are deeply implicated in these chronic situations yet international interventions do not take them into account. For example, there is now considerable evidence pointing to the unintended consequences of intervention, such as its contributions to the sex trade and to violent war economies. ${ }^{84}$ Dyan Mazurana observes that women and gender are seen as 'soft' or peripheral issues in conflict and post-conflict situations and are thus easily postponed to be dealt with after the 'hard' problems of establishing new governmental or economic structures are resolved..$^{85}$ In this sense, interventions regularly reinforce the unequal and oppressive political and social systems that have caused and sustained the immediate conflict. The increasing fusion of humanitarian and military goals in international interventions thus pushes questions of social justice off the agenda.

Gendered images frame the rationale for the responsibility to protect principle. A major catalyst for the concept was the international inaction during the Rwanda genocide in $1994 .{ }^{86}$ Nesam McMillan has shown how the discourse of the 'horrors' of the failure of the international community to rescue the Tutsis has created an image of Western responsibility for global order in the face of the brutal, atrocious behaviour of non-Western peoples. ${ }^{87}$ This image is both masculinised and racialised, in that it

produce[s] a mode of thinking about the response [to the Rwandan genocide] that both figures the West as the global actor and calls upon this global actor to have the will to intervene in non-Western countries around the world on the basis of its relative superiority. ${ }^{88}$

${ }^{82}$ Evans, The Responsibility to Protect, p. 145.

83 Dyan Mazurana, 'Gender and the Causes and Consequences of Armed Conflict' in Dyan Mazurana, Angela Raven-Roberts and Jane Parpart (eds.), Gender, Conflict, and Peacekeeping (Boulder, Colorado: Rowman and Littlefield, 2005), pp. 30-1.

${ }^{84}$ Mazurana, 'Gender and the Causes and Consequences of Armed Conflict', pp. 34-6.

${ }^{85}$ Ibid., p. 40.

${ }^{86}$ For example, Evans, The Responsibility to Protect, pp. 66, 105.

${ }^{87}$ Nesam McMillan, “'Our” Shame: International Responsibility for the Rwandan Genocide', Australian Feminist Law Journal, 28: 3-28 (2008).

${ }^{88}$ Ibid., p. 20. 
The deployment of gendered images in the responsibility to protect doctrine makes it appear a logical, strong and appropriate response to violence. The international community is positioned as the ultimate guarantor of stability and peace. The principle however does not deal with the complexities of the situation of groups who do not wield public power. It does not address the widespread subordination of women or the way that violence shapes women's lives. Military force is presented as a last resort to enforce the principle, but this carries with it the possibility of exacerbating women's inequality and oppression. It also has the effect, as Karen Engle has argued, of forcing those who want to redress a major problem of presenting it in terms of a crisis that only immediate military intervention can resolve'. ${ }^{89}$ 'This can in turn obscure how both military and non-military interventions have themselves contributed to the crisis, and how international intervention is typically followed by a period of international administration that creates new forms of dependence, powerlessness and exploitation..$^{90}$

\section{Conclusion}

For international lawyers, the development of the responsibility to protect doctrine has been a striking feature of the first decade of the twenty-first century, reconceptualising understandings of the duties of states and the international community when faced with potential or actual atrocities. It has shown not only the significance of norm-entrepreneurs in identifying and publicising new ideas, but also the resilience of the traditional concept of sovereignty. The designers of the responsibility to protect are animated by the hope of ending mass atrocities 'once and for all'; while they see themselves as breaking new ground by placing the interests of vulnerable populations first, some states regard them as the vanguard of neo-colonialism.

Given the resistance the doctrine has encountered politically, its international legal status is uncertain. It may be that it is not capacious enough to embrace all the contradictory interests at stake, unlike concepts such as 'sustainable development', or 'proportionality' and 'reasonableness' in the laws of war, which, as Koskenniemi points out, is the essence of international law. ${ }^{91}$

\footnotetext{
89 Engle, "Calling in the Troops", p. 190.

${ }_{90}$ Orford, Reading Humanitarian Intervention, pp. 28-31.

${ }_{91}$ Martti Koskenniemi, 'International Law in the World of Ideas' in James Crawford and Martti Koskenniemi (eds.), Cambridge Companion to International Law (Cambridge: Cambridge University Press, 2011) (forthcoming).
} 
Feminist scholars have an ambivalent attitude to international law, sometimes working to extend its coverage and sometimes worrying that invoking it may legitimate oppressive state structures. I think it worth engaging with concepts such as the responsibility to protect because they can unsettle the standard boundaries of the discipline and increase the possibility of its transformation. As the history of Security Council Resolution 1325 shows, international developments can also inspire and support local action to promote women's equality. ${ }^{92}$ However, I have argued that, from a feminist perspective, the responsibility to protect doctrine has been devised within a very limited context. It has paid desultory attention to women's lives and has reinforced gendered and racialised accounts of peace and conflict and the capacity of intervention to defuse violence. For the doctrine to offer support for women's equality, it would need to take into account a broader set of factors that impinge on women's lives, including women's economic marginalisation, the effect of militarisation and systemic discrimination against women. It would need to engage with the private subordination of women and the widespread violence against them outside the formal structures of the state. It would need to problematise the idea of intervention, recognising that it can exacerbate injustices by reinforcing particular forms of world order. ${ }^{93}$ The responsibility to protect principle would also need to be framed more modestly, not as a single solution to atrocities, but as one strand of a complex response that draws inspiration and ideas from everyone affected by violence. ${ }^{94}$

${ }^{22}$ Dianne Otto, 'The Security Council's Alliance of Gender Legitimacy: The Symbolic Capital of Resolution 1325' in Hilary Charlesworth and Jean-Marc Coicaud (eds.), Faultlines of International Legitimacy (Cambridge: Cambridge University Press, 2010), pp. 263-65.

${ }^{93}$ See generally Orford, Reading Humanitarian Intervention.

${ }^{94}$ An idea suggested by John Braithwaite's account of international law: John Braithwaite, 'Conclusion: Hope and Humility for Weavers with International Law' in Brett Bowden, Hilary Charlesworth and Jeremy Farrall (eds.), The Role of International Law in Rebuilding Societies after Conflict: Great Expectations (Cambridge: Cambridge University Press, 2009). 